\title{
Hasła przedmiotowe MESH a czytelnicy literatury medycznej
}

\begin{abstract}
Subject headings in MESH and readers of medical literature). The goal of this article is to investigate the correlations between medical subject headings in Polish and English and the results of library queries obtained by their application to the JU Medical Library search engine. The Polish and English subject headings are analyzed in terms of their semantic unambiguity and the textual frequency of corresponding medical terms is examined. Attention will be also paid to various translative equivalence types in terms of Polish neoclassical terms included in the complete database of medical subject headings compared to their counterparts in English. The entire analysis is preceded by a concise outline of the historical and theoretical bases of medical subject headings in the research on librarianship and terminology for the sake of investigating languages for specific purposes.
\end{abstract}

\begin{abstract}
Abstrakt. Niniejszy artykuł ma na celu przebadanie korelacji pomiędzy medycznymi hasłami przedmiotowymi (ang. medical subject headings) w języku polskim $i$ angielskim rozpatrywanymi z punktu widzenia ich jednoznaczności semantycznej z terminami medycznymi wykazującymi dodatnią frekwencję tekstową a wynikami kwerend bibliotecznych w wyszukiwarce Biblioteki Medycznej Uniwersytetu Jagiellońskiego uzyskanymi za ich pomocą. Jako istotny uwzględniony zostanie różny typ ekwiwalencji translatywnej w przypadku polskich terminów o neoklasycznej proweniencji funkcjonujących w pełnej bazie medycznych haseł przedmiotowych w stosunku do ich odpowiedników w języku angielskim. Całość analiz poprzedzona zostanie zwięzłym zarysowaniem podstaw historyczno-teoretycznych medycznych hasel przedmiotowych $\mathrm{w}$ terminologii na użytek badania języków specjalistycznych i bibliotekarstwie.
\end{abstract}

\section{Cel i metodologia pracy}

Rozważania przedstawione w niniejszym artykule są niewątpliwie z pogranicza językoznawstwa, w szczególności badania języków specjalistycznych, i bibliotekarstwa, gdyż polsko-angielskie analizy przekładoznawcze terminologii medycznej z odnie- 
sieniem do jej budowy gramatycznej powiązano z wynikami kwerend bibliotecznych dokonanych w zbiorach Biblioteki Medycznej Uniwersytetu Jagiellońskiego, jako że Biblioteka Uniwersytetu Jagiellońskiego ma status biblioteki narodowej. Zasadniczym celem leżącym u podstaw niniejszego opracowania było zbadanie możliwości indywidualnego poszerzenia wiedzy medycznej przez użytkownika księgozbioru bibliotecznego. W tym celu wykorzystano skorowidz jednego $\mathrm{z}$ dostępnych na rynku poradników zdrowotnych wydanego w Wielkiej Brytanii przez Brytyjskie Stowarzyszenie Lekarzy w oryginalnej wersji pod tytułem "The Family Doctor Home Adviser” (1992) i jego polskiego thumaczenia „Lekarz domowy. Rodzinny Poradnik medyczny” wydanego przez Świat Książki. W ten sposób uzyskano w pełni porównywalny, paralelny korpus wzajemnie ekwiwalentnych terminów medycznych zegzemplifikowany w niniejszym artykule na przykładzie pięciu najczęściej występujących terminów w ich polskiej wersji ze względu na język artykułu. Na potrzeby niniejszego badania poprzez analogię do wcześniejszych prac (por. The Oxford History of English) przyjęto założenie, że dany termin medyczny jest zrozumiały dla przeciętnego rodzimego użytkownika danego języka, w tym przypadku języka polskiego i angielskiego, jeżeli wchodzi on w skład ogólnego słownictwa tego języka przejawiającego się w pisemnym dyskursie publicystycznym. Zbadano ich występowanie w postaci słownikowej w Polskim Korpusie Narodowym PWN, Brytyjskim Korpusie Narodowym (British National Corpus) i Amerykańskim Korpusie Współczesnego Języka (Corpus of Contemporary American English) z uwzględnieniem różnic w pisowni tych terminów w zależności od narodowych odmian języka angielskiego. Taki sposób podejścia do analiz terminów medycznych zdaje się również odpowiadać zapotrzebowaniu początkujących studentów uczelni medycznych korzystających z wewnątrzbibliotecznych baz danych, a nie dysponujących jeszcze znajomością specyficznie medycznych terminów niezrozumiałych dla przeciętnego użytkownika języka.

Późniejsze wykorzystanie będących w powszechnym uzusie terminów medycznych jako haseł przedmiotowych rozumianych jako „hasła używane do umiejscowienia pozycji sporządzonych dla dokumentów o podobnej treści" (Sternik) wydaje się uzasadnione nie tylko z powodu ich implementacji do wyszukiwarki pozycji w katalogu, ale także ze względu na pierwotny zamysł twórców koncepcji medycznych haseł przedmiotowych omówiony w zarysie historii na postawie danych $\mathrm{z}$ amerykańskiej National Library of Medicine.

Poza tym szczególną uwagę poświęcono terminom o proweniencji grecko-łacińskiej analizowanych już wielokrotnie pod względem ich właściwości słowotwórczych i semantycznych (por. prace takich autorów, jak ten Hacken 1994, 2012, 2015, Panocova 2012, Machowski 2015, Stroński 1997), gdyż już w indeksie haseł poradnika medycznego (por. Smith 1992) zasugerowano ich dwojaką możliwość przekładu. W ich przypadku dodatkowo rozszerzono zakres kwerendy bibliotecznej o przeszukanie pełnej bazy słownika Głównej Biblioteki Lekarskiej wykazującej w większej skali na możliwość dwojakiego sposobu poszukiwań interesującej czytelnika literatury na podstawie tychże haseł ze względu na sposób ich przetłumaczenia na język polski. 


\section{Zarys historii medycznych hasel przedmiotowych zrekonstruowany na podstawie National Library of Medicine}

Pierwsza oficjalna lista haseł przedmiotowych opublikowana przez Narodową Bibliotekę Medyczną ukazała się w 1954 roku pod tytułem „Subject Heading Authority List". Została ona opracowana nad podstawie wewnętrznej listy hierarchicznej użytej do publikacji obecnej listy literatury medycznej „Current List of Medical Literature”. Wraz z pojawieniem się nowej serii o nazwie „Index Medicus” w 1960 roku ukazała się zaktualizowana i uzupełniona wersja medycznych haseł przedmiotowych. Listy kategorii standardowych podhaseł pojawiły się w 1954 roku wraz z listą hierarchiczną haseł przedmiotowych. Odstępstwa od normy ujęte były na tej liście jako standardowe podhasło używane wraz z terminami nazywającymi organy, tkanki i obszary ciała. Było ponad 100 takich podhaseł stosowanych do nadrzędnych w stosunku do nich kategorii haseł. Na przykład termin ,terapeutyczne zastosowanie” był używany jako podhasło w stosunku do czynników fizycznych leków i środków chemicznych a terminu „terapia" używano do opisu chorób. Według rejestru medycznych haseł przedmiotowych z 1960 roku liczba podhaseł została obniżona do 67. Skategoryzowane listy terminów opublikowano po raz pierwszy jako hasła przedmiotowe w 1963 roku. Zawierały one 13 głównych kategorii i łącznie 58 rozłącznych grup w podkategoriach i głównych kategoriach. Skategoryzowane listy umożliwiły czytelnikowi znalezienie więcej powiązanych terminów niż w poprzedniej przekrojowej strukturze. W 1963 roku drugie wydanie Medycznych Haseł Przedmiotowych zawierało 5700 deskryptorów, czyli o 1300 więcej niż w edycji z 1960 roku. W 1960 roku opublikowano pierwsze wydanie Index Medicus. MESH był wtedy nową i dogłębnie poprawioną wersją list haseł przedmiotowych utworzoną przez Narodową Bibliotekę Medyczną ze względu na jej bibliografie i katalogi. Od samego początku MESH był dynamicznie rozwijającą się listą. Zawartość słownictwa związanego z użyciem terminów w literaturze ewoluowała do ogarnięcia nowych pomysłów w tym polu. Zastosowanie komputera usprawniło i usystematyzowało poprawki i trudności w aktualizacji wydrukowanych indeksów i katalogów kartkowych.

\section{Terminologia języków specjalistycznych a terminy w poradnikach medycznych jako medyczne hasła przedmiotowe}

W pierwszej kolejności wydaje się konieczne nakreślenie filologicznej perspektywy niniejszych rozważań poprzez wskazanie gałęzi badań filologicznych traktującej o właściwościach terminologii i frazeologii medycznej wraz z słownictwem przynależnym do bibliotekarstwa medycznego, w skład którego wchodzą medyczne hasła przedmiotowe jako standardowe formy terminów medycznych (Leon-Arauz 2015: 
38). Wydaje się nią być językoznawstwo medyczne (medical linguistics) (por. SadeghZadeh, K. 2015: 51) w definicji którego również dane kwantowane i medyczne dane bibliotekarskie podlegają analizie lingwistycznej w zestawieniu z medicolingwistyką (ang. medicolinguistics; Machowski 2015: 179) skupiającą się na semazjologicznych właściwościach terminologii medycznej (Machowski 2015) dotychczas zawartej w prasie specjalistycznej bez odniesienia do zagadnień z informacji naukowej. Już na mocy samej definicji medycznych haseł przedmiotowych postulowanej przez jej twórców (por. pkt. 2) uznawane są one za terminy, jednak o ich przynależności do terminów specjalistycznych decyduje spełnienie przez nich kluczowego wymogu definicyjnego, czyli spełnienia przez nich przede wszystkim funkcji kognitywno-praktycznych a także komunikacyjnych (por. Grucza 1991: 35), co obrazują chociażby takie terminy zawarte w poradnikach (por. Smith 1992), jak gruźlica, choroba Heinego-Medina, czy ból neuralgiczny. Tożsamość podanych powyżej przykładowych terminów z odpowiadającymi im medycznymi hasłami przedmiotowymi daje asumpt do dokonania kwerend bibliotecznych z ich wykorzystaniem.

\section{Terminy medyczne a kwerenda biblioteczna}

W ścisłym odniesieniu do przedstawionych we wstępie założeń niniejszej pracy terminy medyczne znajdują także swoje zastosowanie jako hasła przedmiotowe w celu wyszukania przez czytelnika biblioteki interesującej go literatury przedmiotu. Zebrany na potrzeby niniejszej pracy dwujęzyczny zbiór wzajemnie porównywalnych terminów zostanie w pierwszej kolejności zegzemplifikowany za pomocą 5 najczęściej występujących terminów w ogólnym języku polskim zaczerpniętych z pozycji „Lekarz domowy. Rodzinny Poradnik medyczny” (2002) wraz z informacją frekwencyjną o ich występowaniu w języku angielskim. Z językoznawczego punktu widzenia warto również wspomnieć o ich łączącej ich relacji homosygnifikacji (por. Bańczerowski i in. 1982: 193) z odpowiadającymi im wyrazami języka ogólnego, czyli wskazywania na ten sam obiektów (Bańczerowski i in. 1982: 195), co świadczy o ich jednoznaczności semantycznej i umożliwia interlingwalną komparację zarówno jako terminów medycznych, jak i wyrazów języków naturalnych. Ponadto zbadanie częstości występowania tychże terminów w ogólnym języku polskim (por. korpus PWN), jak i w narodowych korpusach języka angielskiego (korpusy COCA i BNC) potwierdza powszechność ich użycia we współczesnym języku angielskim i polskim. Poza tym, także w odniesieniu do języka angielskiego, powyższe pomiary unaoczniają ich zróżnicowaną frekwencyjnie przynależność do różnych warstw leksykalnych języka angielskiego w dwóch odmianach, wynikającą z różnorodnego zasobu językowego będącego podstawą uzyskania powyższych danych liczbowych. W przypadku Korpusu Współczesnej Amerykańskiej Angielszczyzny zasobem leksykalnym jest zbiór transkryptów tekstów mówionych, fikcji literackiej, magazynów popularno-naukowych, 
gazet i czasopism naukowych (por. Davis 2010:447-464), a w przypadku Brytyjskiego Korpusu Narodowego zbiorem zróżnicowanych społecznie i demograficznie tekstów pisanych i mówionych odzwierciedlających angielszczyznę różnych klas społecznych (por. Burnard \& Aston 1998).

\begin{tabular}{|c|c|c|c|c|}
\hline polski termin & $\begin{array}{c}\text { tokeny } \\
\text { w korpusie } \\
\text { PWN }\end{array}$ & $\begin{array}{c}\text { angielski } \\
\text { termin }\end{array}$ & $\begin{array}{c}\text { tokeny } \\
\text { w COCA }\end{array}$ & $\begin{array}{c}\text { tokeny } \\
\text { w BNC }\end{array}$ \\
\hline apetyt & 300 & appetite & 4953 & 848 \\
\hline koordynacja & 281 & coordination & 4910 & 462 \\
\hline przeziębienie & 264 & cold & 66569 & 11541 \\
\hline alergia & 248 & allergy & 2012 & 220 \\
\hline klatka piersiowa & 221 & chest & 28876 & 3543 \\
\hline
\end{tabular}

Po wprowadzeniu tychże terminów do wyszukiwarki jako hasła przedmiotowe uzyskujemy następujące wyniki kwerendy: 


\begin{tabular}{|c|c|c|c|c|c|}
\hline 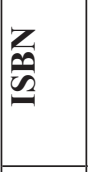 & 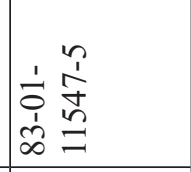 & 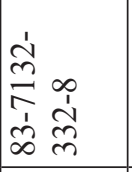 & & 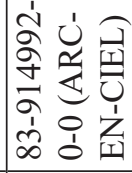 & $\begin{array}{ll}1 & \\
2 & \\
2 & 2 \\
1 & 2 \\
\infty & 0 \\
\infty & 0\end{array}$ \\
\hline 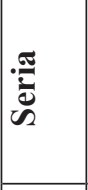 & 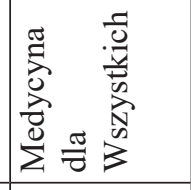 & 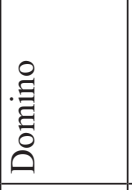 & & & 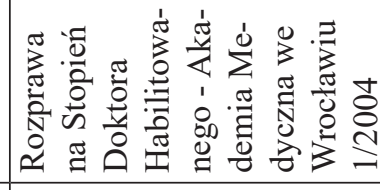 \\
\hline 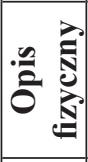 & 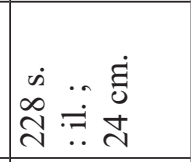 & 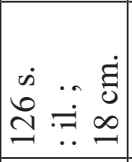 & 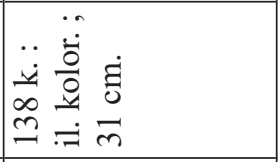 & $\begin{array}{ll}a & \dot{1} \\
\dot{m} & \tilde{0} \\
\hat{\theta} & \bar{v}\end{array}$ & 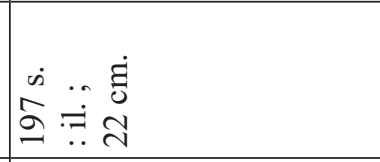 \\
\hline 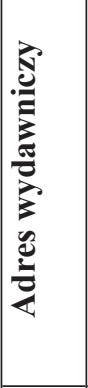 & 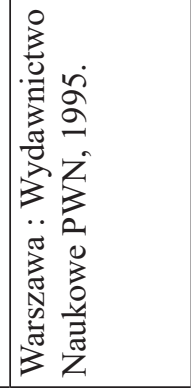 & 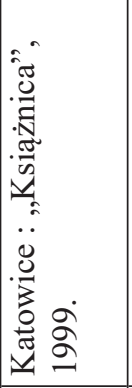 & 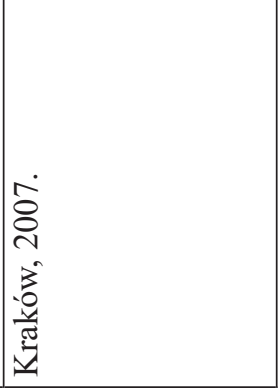 & 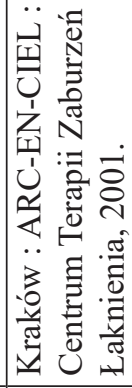 & 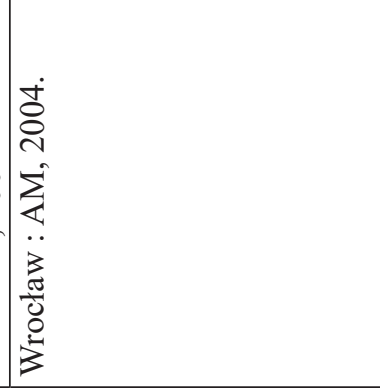 \\
\hline לֶ. & & & & & \\
\hline 竎 & 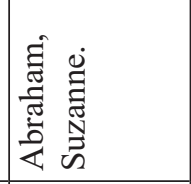 & 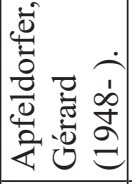 & 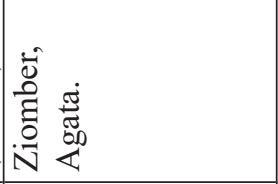 & 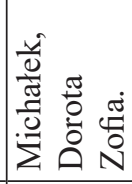 & 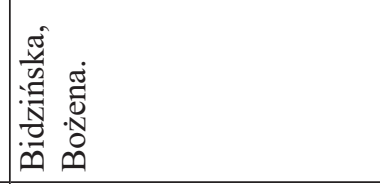 \\
\hline 焉 & 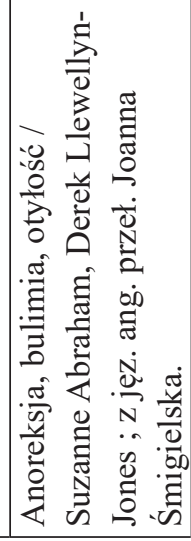 & 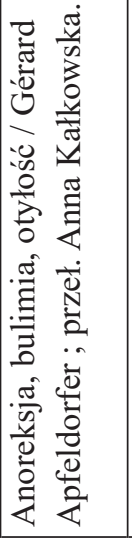 & 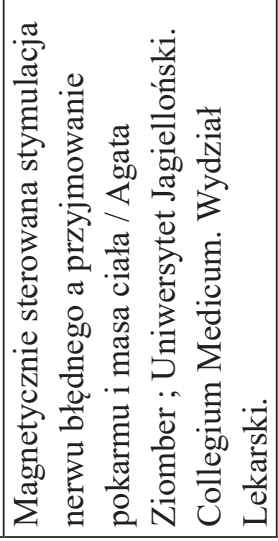 & 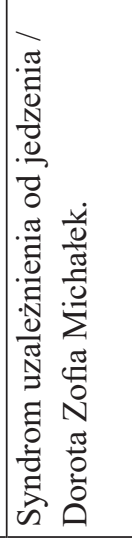 & 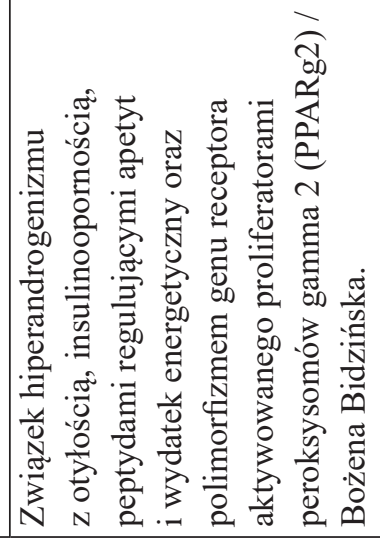 \\
\hline
\end{tabular}




\begin{tabular}{|c|c|c|c|}
\hline 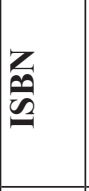 & 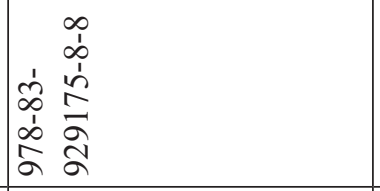 & 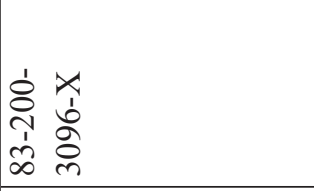 & 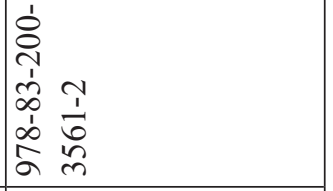 \\
\hline . & & & \\
\hline ○े & 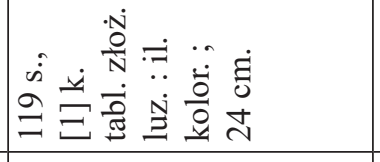 & $\begin{array}{lll}\Xi & \cdots & \dot{E} \\
\infty & \Xi & 0 \\
\infty & \dot{n} & d \\
\end{array}$ & $\begin{array}{lll}\Xi & \cdots & \dot{\Xi} \\
\infty & \cdots & 0 \\
\infty & \dot{n} & d\end{array}$ \\
\hline 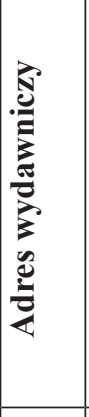 & 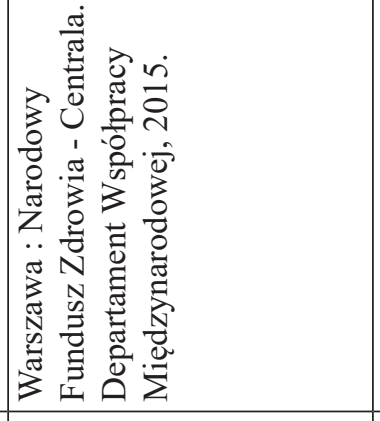 & 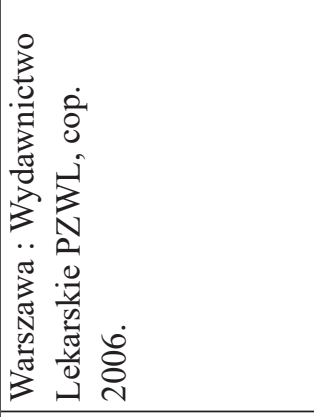 & 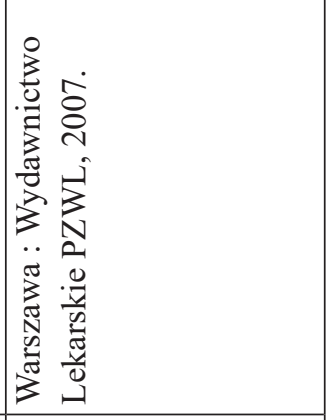 \\
\hline ל气. & 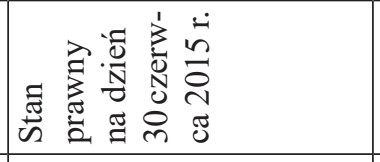 & & 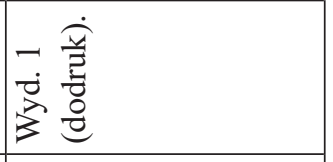 \\
\hline 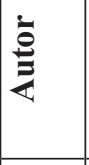 & 密 & & \\
\hline 忢 & 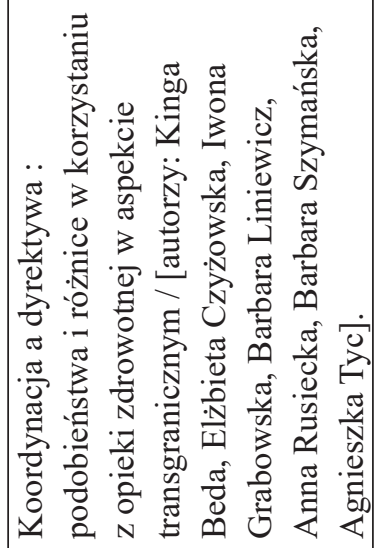 & 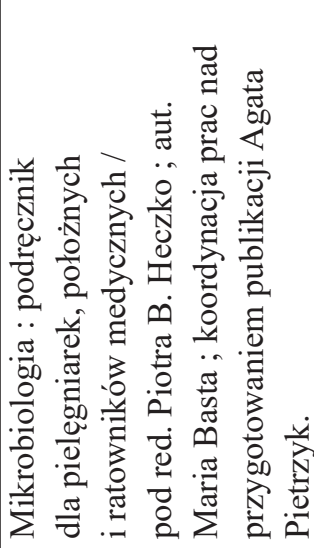 & 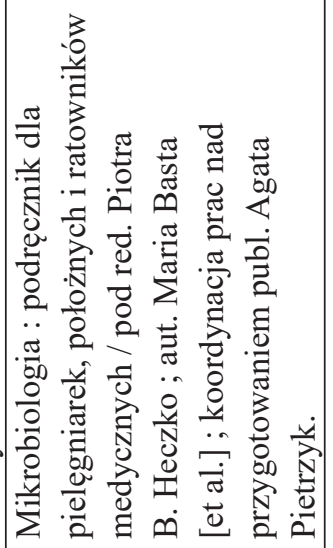 \\
\hline
\end{tabular}




\begin{tabular}{|c|c|c|c|c|c|}
\hline 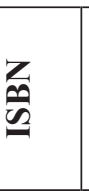 & $\begin{array}{ll}1 & \\
\infty & \\
\infty & \\
\infty & \\
\infty & \\
\infty & a \\
1 & \vdots \\
\infty & 8 \\
\infty & 8 \\
\end{array}$ & 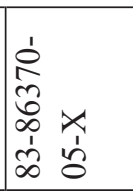 & 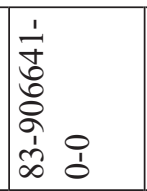 & 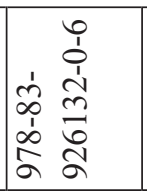 & $\begin{array}{ll}1 & \\
n & \\
0 & \\
n & \\
\infty & n \\
1 & 1 \\
n & n \\
\infty & 0\end{array}$ \\
\hline 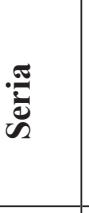 & 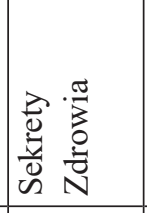 & 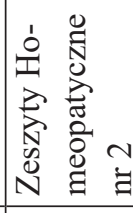 & & & 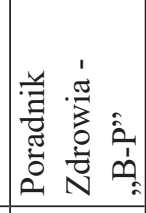 \\
\hline 党 & $\begin{array}{ll}\ddot{n} & \dot{g} \\
\cong & \bar{v} \\
\Xi & \vec{v}\end{array}$ & $\begin{array}{ll}\ddot{1} & \dot{j} \\
\dot{n} & 0 \\
\dot{v} & n \\
& n\end{array}$ & \begin{tabular}{ccc|}
$\dot{m}$ &. & $\dot{0}$ \\
$\infty$ & $\ddot{n}$ & 0 \\
& $\cdots$ & $\bar{v}$ \\
\end{tabular} & 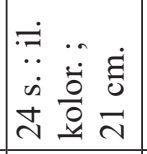 & 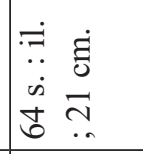 \\
\hline 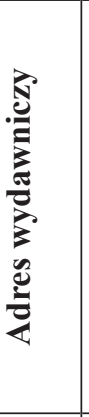 & 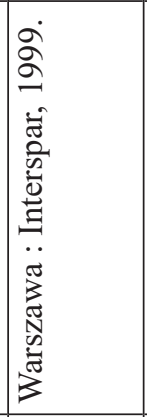 & 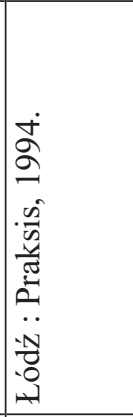 & 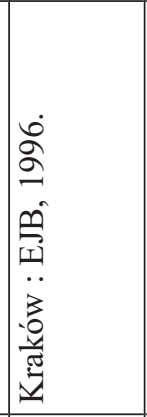 & 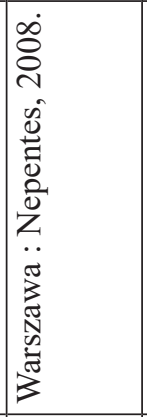 & 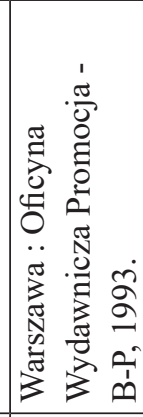 \\
\hline 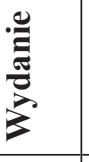 & & & & $\mid \begin{array}{l}i \\
i \\
0 \\
3 \\
3 \\
3\end{array}$ & \\
\hline 总 & 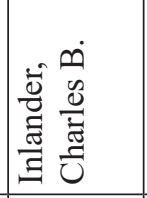 & 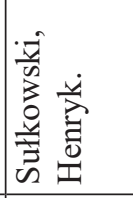 & 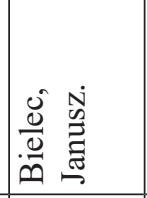 & 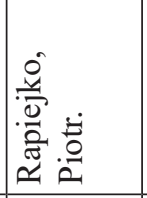 & 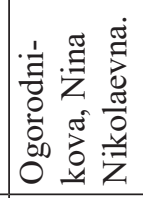 \\
\hline 竧 & 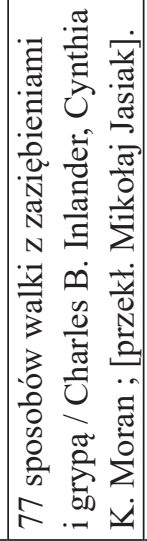 & 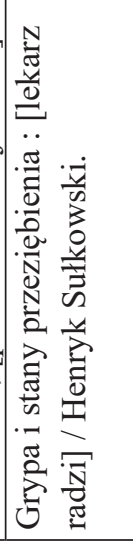 & 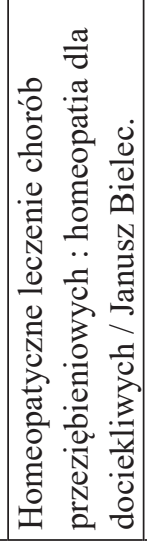 & 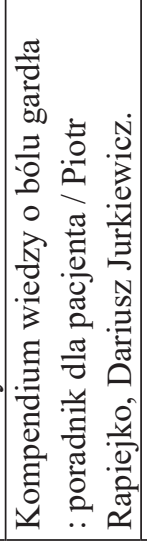 & 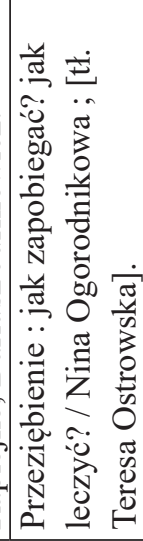 \\
\hline
\end{tabular}




\begin{tabular}{|c|c|c|c|c|c|}
\hline$\frac{Z}{\mathscr{a}}$ & $\begin{array}{ll}1 & \\
\infty & \\
\infty & \\
\infty & \\
\infty & 9 \\
1 & 1 \\
\infty & 0 \\
\infty & 0 \\
\end{array}$ & & $\begin{array}{cc} & + \\
1 & \vdots \\
& \infty \\
0 & m \\
1 & \cdots \\
\infty & 0 \\
\infty & 0\end{array}$ & & \\
\hline 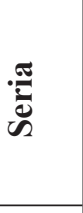 & 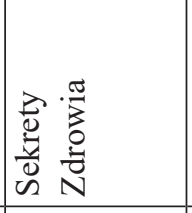 & & & 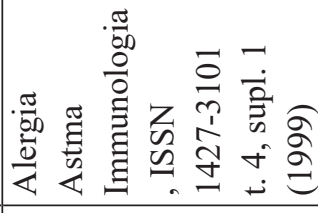 & \\
\hline ڤ. & $\begin{array}{ll}\ddot{m} & \dot{\Xi} \\
\stackrel{0}{J} & \bar{v}\end{array}$ & $\begin{array}{l}\text { छ் } \\
\text { ปे }\end{array}$ & 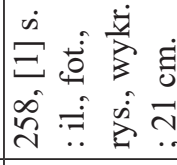 & $\begin{array}{ll}\ddot{\pi} & \\
\ddot{1} & \dot{\Xi} \\
\dot{0} & 0 \\
0 & \Omega े \\
= & \cdots\end{array}$ & $\begin{array}{l}\text { छ் } \\
\text { Әे } \\
\text { वे }\end{array}$ \\
\hline 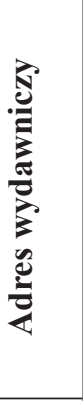 & 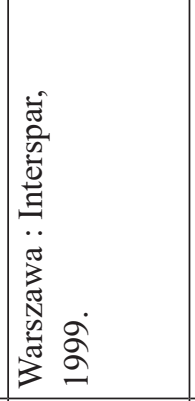 & 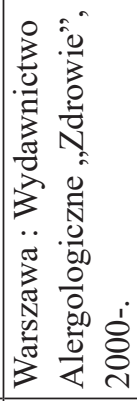 & 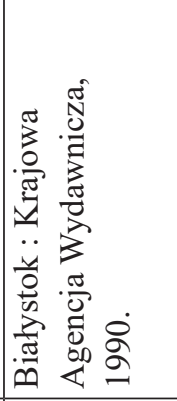 & 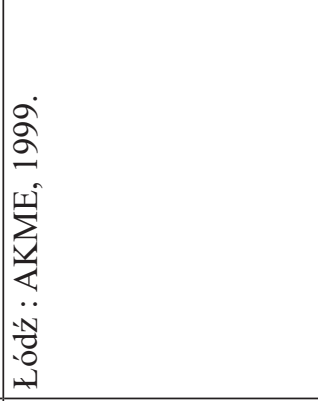 & 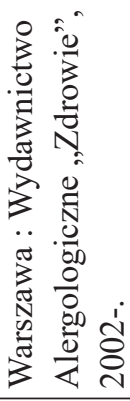 \\
\hline 苞 & & & & & \\
\hline$\stackrel{\grave{\partial}}{\varrho}$ & 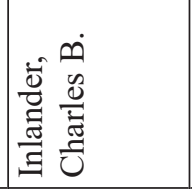 & & 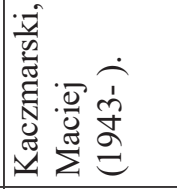 & & \\
\hline$\underset{E}{E}$ & 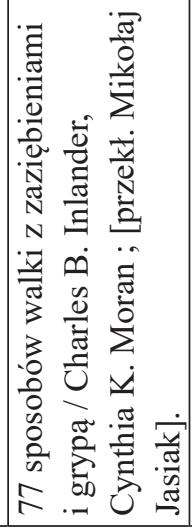 & 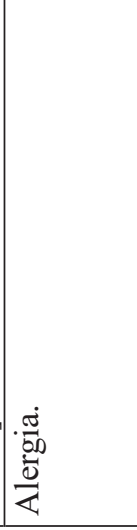 & 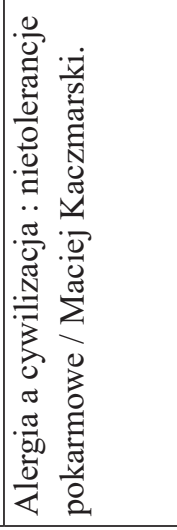 & 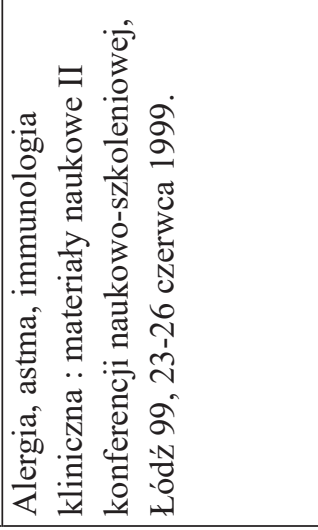 & 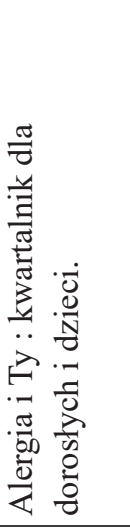 \\
\hline
\end{tabular}




\begin{tabular}{|c|c|c|c|c|c|}
\hline $\begin{array}{l}Z \\
\mathbb{B} \\
\mathbb{B}\end{array}$ & $\begin{array}{l}1 \\
1 \\
\infty \\
2 \\
\hat{0} \\
1 \\
0 \\
0 \\
\hat{1} \\
\tilde{\infty} \\
\infty\end{array}$ & 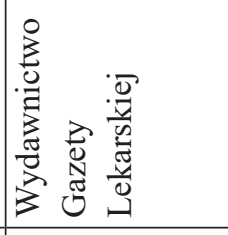 & & & \\
\hline & 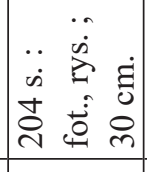 & 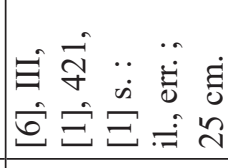 & 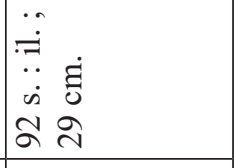 & 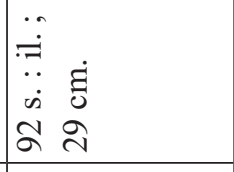 & 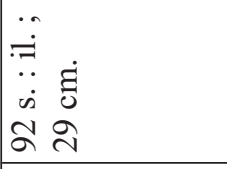 \\
\hline 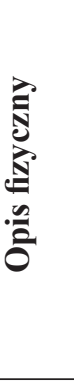 & 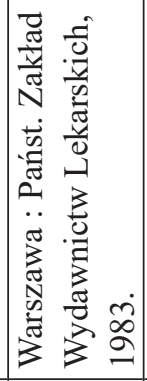 & 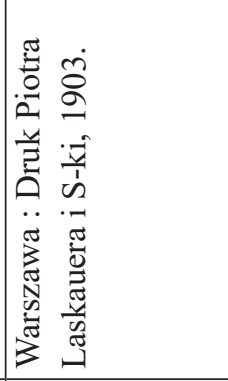 & 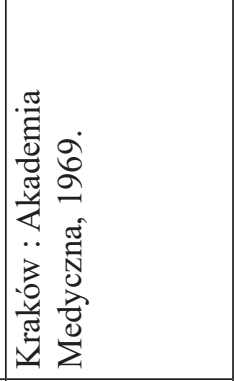 & 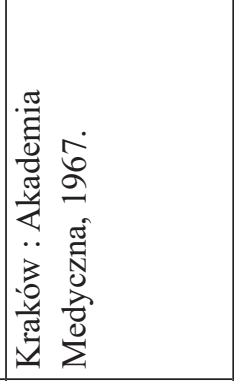 & 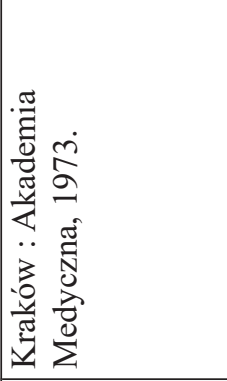 \\
\hline ह & & & $\begin{array}{l}i \\
\dot{3} \\
3\end{array}$ & & $\begin{array}{l}\dot{m} \\
\dot{3} \\
\overrightarrow{3}\end{array}$ \\
\hline 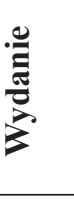 & 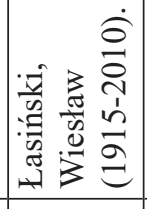 & 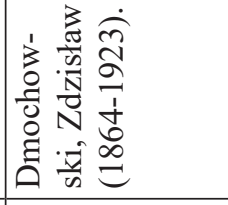 & 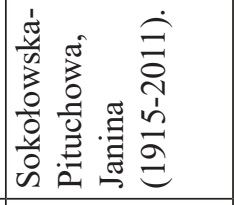 & 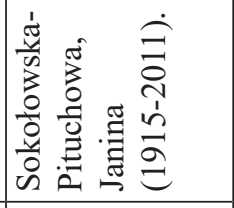 & 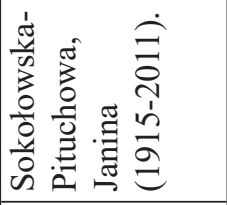 \\
\hline 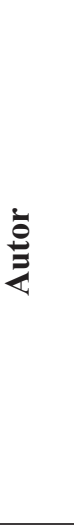 & 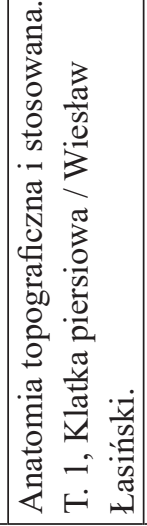 & 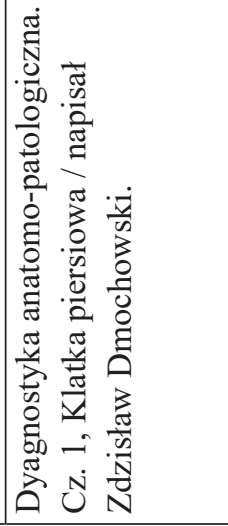 & 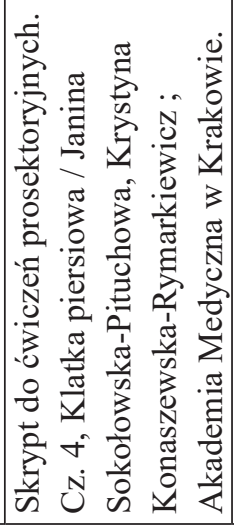 & 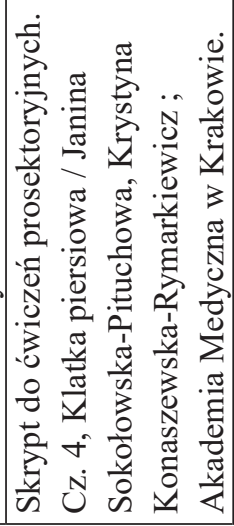 & 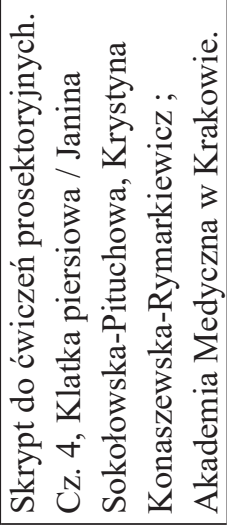 \\
\hline
\end{tabular}


Powyższe wyniki kwerendy wskazują na to, że można uzyskać za ich pomocą dostęp do

(i) repozytoriów referatów medycznych, jak na przykład w przypadku terminów przeziębienie zawierających indywidualny dorobek prac na ten temat autorstwa badaczy z różnych ośrodków,

(ii) atlasów anatomicznych i skryptów do ćwiczeń prosektoryjnych,

(iii) książek z pogranicza nauk medycznych i chemicznych/społecznych, jak w przypadku pozycji o koordynacji lub alergii.

\subsection{Terminy medyczne o neoklasycznej proweniencji a wyniki kwerend w zasobach Głównej Biblioteki Lekarskiej}

Poprzez odniesienie się do wzmianki o nich we wstępie do niniejszej pracy warto rozważyć istotę problemu ich przekładu na przykładzie terminu o neoklasycznej strukturze psychoterpia zawartego również w Poradniku Domowym, który thumaczy się słownikowo na język polski za pomocą techniki odwzorowania (Kubacki 2009: 5 za Illuk 2008: 123), jednak na potrzeby utworzenia szczegółowych medycznych haseł przedmiotowych stosuje się jego przekład poprzez zastosowanie techniki poszerzenia elementów grupy wyrazowej (Kubacki 2009: 5 za Illuk 2008: 123), co ilustrują następujące przykłady:

A.

\begin{tabular}{|l|l|}
\hline Deskryptor polski: & Psychoterapia grupowa \\
\hline Deskryptor MeSH: & Psychotherapy, Group \\
\hline
\end{tabular}

B.

\begin{tabular}{|l|l|}
\hline Deskryptor polski: & Psychoterapia krótka \\
\hline Deskryptor MeSH: & Psychotherapy, Brief \\
\hline
\end{tabular}

Uzyskane w ten sposób polskie hasła przedmiotowe są z punktu widzenia przekładoznawstwa ekwiwalentami o węższym znaczeniu niż ich angielskie odpowiedniki w ich znaczeniu słownikowym. Taki model generowania haseł przedmiotowych w języku polskim dotyczy angielskich terminów o neoklasycznej strukturze z punktu widzenia słowotwórstwa.

Oto kolejne przykłady:

C.

\begin{tabular}{|l|l|}
\hline Deskryptor polski: & Kiła skóry \\
\hline Deskryptor MeSH: & Syphilis, Cutaneous \\
\hline
\end{tabular}


D.

\begin{tabular}{|l|l|}
\hline Deskryptor polski: & Kiła układu krążenia \\
\hline Deskryptor MeSH: & Syphilis, Cardiovascular \\
\hline
\end{tabular}

E.

\begin{tabular}{|l|l|}
\hline Deskryptor polski: & Kiła układu nerwowego \\
\hline Deskryptor MeSH: & Neurosyphilis \\
\hline
\end{tabular}

\section{Wnioski}

Na podstawie przeprowadzonego badania korelacji wzajemnie translatywnie ekwiwalentnych terminów medycznych o dodatniej frekwencji tekstowej w języku polskim i angielskim można stwierdzić, że

1. zestaw haseł przedmiotowych MESH zgodnie z pierwotnym założeniem jego twórców odpowiada terminom medycznym będącym w powszechnym użyciu i umożliwia czytelnikom biblioteki znalezienie pozycji książkowych o charakterze repozytoriów, podręczników akademickich oraz utworów z pogranicza nauk medycznych i społecznych. Powyższa obserwacja zdaje się potwierdzać wprowadzone na wstępie domniemanie, że istnieje zależność pomiędzy wynikami kwerend bibliotecznych a wyszukiwanymi w katalogu bibliotecznym hasłami przedmiotowymi. Ponadto sugeruje on uzyskanie jak najszerszego spektrum tematycznego pozycji $\mathrm{z}$ medycznej literatury przedmiotu poprzez prowadzenie kwerend $\mathrm{w}$ polskich i anglojęzycznych bazach danych za pomocą haseł o ogólnym znaczeniu,

2. w przypadku polskich i angielskich terminów o proweniencji grecko-łacińskiej uzyskuje się generalnie bardziej urozmaicone rezultaty poszukiwań za pomocą haseł o paralelnej, neoklasycznej strukturze w obydwu językach, na co wskazują kwerendy biblioteczne w pełnej bazie medycznych haseł przedmiotowych.

\section{Bibliografia}

Bańczerowski, J. 2000: Is linguistic semantics axiomatically tangible? Scripta Neophilologica Posnaniensia II. Poznań: Wydawnictwo UAM. 13-20.

Bańczerowski, J., Pogonowski, J. \& Zgółka, T. 1982: Wstęp do językoznawstwa 'Introduction to linguistics'. Poznań: Adam Mickiewicz University Press.

Burnard, L. \& Aston, G. 1998: The BNC handbook: exploring the British National Corpus. Edinburgh: Edinburgh University Press. 
Davies, M 2010: The Corpus of Contemporary American English as the First Reliable Monitor Corpus of English. Literary and Linguistic Computing 25 (4): 447-65.

Grucza S. 2013: Studi@ Naukowe. t. 2: Od lingwistyki tekstu do lingwistyki tekstu specjalistycznego [From text linguistics to specialist text linguistics]. Warszawa: Wydawnictwo Naukowe IKL@.

Iluk, J. 1998: Problemy thumaczenia nazw medycznych na przykładzie języka polskiego i niemieckiego. Glottodidactica XXVI. Poznań: Wydawnictwo Naukowe UAM. 123-136.

Kościałkowska-Okońska, E. 2012: Translating medical texts for legal purposes: A growing challenge for court translators and interpreters. Comparative legilinguisitics 11/7. Poznań: Wydział Neofilologii UAM. 7-21.

Kubacki, A. 2009: Relacje interlingwalne między niemieckimi derywatmi z-ung a ich odpowiednikami w języku polskim. Investigationes Linguisticae XVII. Poznań: UAM. 1-14.

Machowski, Sz. 2015: Compounding Properties and Translation Methods of Terms in the Domain of Infectious Diseases. In: ten Hacken, P., Panocova, R. (eds): Word Formation and Transparency in Medical English. Newcastle upon Tyne: Cambridge Scholars Publishing. 179-200.

Matulewska, A., Matulewski, M. 2005: Język logistyki. Wpływ języka angielskiego na język polski. Logistyka 5. Poznań: Instytut Logistyki i Magazynowania.

Mugglestone, L. 2006: The Oxford History of English. Oxford: Oxford University Press.

Panocová, R. 2012: Morphological properties of neoclassical formations in English. Bulletin of the Transilvania University of Brasov. Philology and Cultural Studies 5 (54) 2: 31-36.

Pilar, L-A. 2015: Term Variation in the Psychiatric Domain: Transparency and Multidimensionality. In: ten Hacken, P., Panocova, R. (eds.): Word Formation and Transparency in Medical English. Newcastle upon Tyne: Cambridge Scholars Publishing. 33-54.

Resurreccio, V. M. Davies \& Gonzalez Davis, M. 2007: Medical Translation Step by Step. Manchester: St Jerome.

Sadegh-Zadeh, K. 2015: Medical Linguistics. Handbook of Analytic Philosophy of Medicine 19. Dordrecht: Springer. 51-58.

Smith, T. 1992: New Family Doctor Home Adviser, The practical quick-reference guide to symptoms and how to deal with them. Londyn: British Medical Association.

Stroński, K. 1998: Derywacja a kompozycja. Status greki 'Wordformation vs. Compounding. The Status of Greek’. In: Artis linguisticae paululum. N. Kordek i K. Stroński (eds). Poznań: UAM.

ten Hacken, P. 2015: Naming Devices in Middle-Ear Surgery: A Morphological Analysis. In: ten Hacken, P. \& Panocova, R. (eds): Word Formation and Transparency in Medical English . Newcastle upon Tyne: Cambridge Scholars Publishing. 55-72.

\section{Serwisy internetowe:}

STERNIK - słownik terminologiczny z zakresu bibliografii i katalogowania. sternik.bn.org.pl/vocab/ index.php (otwarto 11.11.2017)

U.S. National Library of Medicine https://www.nlm.nih.gov/mesh/intro_hist.html (otwarto 26.10.2017)

The Oxford History of English https:/global.oup.com/academic/product/the-oxford-history-ofenglish-9780199660162? cc $=$ pl\&lang $=$ en \& 